\title{
Endüstri Mirasının Korunması ve Dönüşümü: Malatya Şeker Fabrikası Yerleşkesi Örneği
}

\author{
Fahriye Yavaşoğlu 1 \\ ORCID: 0000-0003-0771-237X
}

\author{
Can Giray Özgül ${ }^{2}$ \\ ORCID: 0000-0001-8569-6518
}

\section{Öz}

Ekonomik yeniden yapılanma, sermayenin mantığ ve ihtiyaçları doğrultusunda kentsel mekân dönüşü̈rmekte ve kentsel politikanın belirlenmesinde merkezi bir konumda bulunmaktadır. Dolayısıyla mekân politikaları çerçevesinde 1980 sonrası gerçekleştirilen kentsel dönüşüm uygulamaları, kentsel mekânı sermaye için yatırım alanına dönüştürmektedir. Sermaye birikimine yönelik dönüşüm uygulamalarıla kentsel mekânların biçiminin, işlevinin ve algsının yeniden üretildiğini ve yaşam biçiminin dönüştürüldü̈̆̈̈nü söylemek mümkündür. Bu bağlamda endüstri mirası ve kültürel miras olarak değerlendirilebilecek endüstri alanlar da tarihsel, toplumsal ve kültürel değeri gözetilmeksizin çeşitli gerekçelerle kentsel değişim değeri (toprak rantı, spekülasyon) ön planda tutularak dönüştürülmektedir. Bir başka ifadeyle, üretimin yerini alan inşaat ve finans sektörleri, işlevini yitirdikleri veya kent içinde atıl alanlar oldukları iddiasıyla kamu mülkiyetinde olan endüstri alanlarına yönelmektedir. Özelleştirme ve sanayisizleşme gibi neoliberal uygulamalar, ekonomik ve yapısal dönüşümlerle bağıntılı olarak, Türkiye'de şeker rejimini de yeniden düzenlemiştir. Şeker rejiminin yeniden düzenlenmesine yönelik mevzuat değişiklikleri (1996) kapsamında, şeker fabrikaları yerleşkeleri ve taşınmazları özelleştirme programına alınmış (2000) ve neticesinde Cumhuriyetin ilk sanayi yatırımları olan Şeker Fabrikası Yerleşkelerinde mülkiyet dönüşümleri ve fiziksel yapı dönüşümleri başlamıştır. Çalışma, Türkiye'de devlet eliyle kurulan endüstri yerleşkelerinden biri olan Malatya Şeker Fabrikası Yerleşkesi'nin kuruluşundan günümüze geçirdiği dönüşümü ele almakta ve endüstri mirası olarak korumak yerine müdahaleler sonucu farklı ekonomik sektörlerin kullanımına açılmasımı tartışmaktadır.

Anahtar Kelimeler: kentsel dönüşüm, endüstri mirası, kültür mirası, Malatya Şeker Fabrikası, özelleştirme

\footnotetext{
${ }^{1}$ Arş. Gör., Gazi Üniversitesi, E-mail: fahriyeyavasoglu@gmail.com

${ }^{2}$ Dr. Öğr. Üyesi, Ankara Üniversitesi, E-mail: ozgul@politics.ankara.edu.tr.

idealkent @ Kent Araştırmaları Dergisi (Journal of Urban Studies) 


\title{
Conservation and Transformation of Industrial Heritage: The Case of Malatya Sugar Factory Campus
}

\author{
Fahriye Yavaşoğlu ${ }^{3}$ \\ ORCID: 0000-0003-0771-237X
}

\author{
Can Giray Özgül ${ }^{4}$ \\ ORCID: 0000-0001-8569-6518
}

\begin{abstract}
Economic restructuring transforms urban space in line with the logic and needs of capital. Also it plays a central role in determining urban policy. Therefore, urban transformation practices transform urban space into an investment area for capital after 1980's. It is possible to say that the form, function and perception of urban spaces are reproduced and life style is transformed with the transformation practices towards capital accumulation. In this context, industrial areas which can be considered as industrial heritage and cultural heritage are also transformed by keeping exchange value in the foreground for various reasons regardless of historical, social and cultural value. In other words, the construction and finance sectors, which replace production, have turned to publicly owned industrial areas, claiming that they have lost their function or are idle areas. Neoliberal implementations such as privatization and de-industrialization in connection with economical and structural transformation, have revised the Sugar regime in Turkey. Within the scope of the legislative amendments (1996) regarding the reorganization of the sugar regime, sugar factories settlements and their real estate property were included in the scope of privatization (2000); and ownership and physical structure of the Sugar Factory Settlements were transformed. This study examines the historical transformation process of the Malatya Sugar Factory Settlement as one of the industrial settlements established by the state in Anatolia. It also discusses the opening of the campus to different economic sectors as a result of interventions rather than protection as an industrial heritage.
\end{abstract}

Keywords: urban transformation, industrial heritage, cultural heritage, Malatya Sugar Factory, privatization

${ }^{3}$ R. A., Gazi University, E-mail: fahriyeyavasoglu@gmail.com

${ }^{4}$ Asts. Prof., Ankara University, E-mail: ozgul@politics.ankara.edu.tr.

idealkent @ Kent Araştırmaları Dergisi (Journal of Urban Studies)

http://idealkentdergisi.com

Geliş Tarihi Received Date: 28.01.2020 Kabul Tarihi Accepted Date: 25.06.2020 


\section{Giriş}

Cumhuriyetin sanayileşme sürecini, ekonomik, mekânsal ve toplumsal yeniden yapılanmayı kapsayan modernleşme deneyimi ile iç içe geçmiş bütüncül bir politika olarak tanımlamak gerekmektedir. 17. yüzyıldan itibaren ortaya çıan ve Avrupa'daki toplumsal yaşam ve organizasyon biçimi olarak tanımlanan modernite, bireysel, toplumsal, kurumsal ve ekonomik olmak üzere dört temel boyutta ele alınmaktadır. Modernite Avrupa dışındaki toplumlarda, kapitalizmin işleyişi çerçevesinde kendiliğinden gelişen bir değişme veya reformist kurumsal düzenlemeler ile sosyal mühendislik müdehaleleri kullanılarak uygulamaya geçirilmiştir. (Tekeli, 1995, s. 51-2.). Yeni kurulan Cumhuriyetin modernite projesi, ekonomik, teknolojik ve toplumsal politikalar üzerinden mekân ile ilişkilendirilerek, mekânsal politikalar ile birlikte uygulamaya geçmiştir. Bu kapsamda, öncelikli olarak bir tüketim ihtiyacını karşılamak ve modern üretime geçmek amacıyla kurulan fabrikaların, birey ve toplumun yeniden üretildiği, birer yerleşke/yaşam alanı olarak tasarlandıkları ve kurulduklarını söylenebilir. Kuruldukları yerlerde kentleşme pratiğini etkilediği bilinen fabrika yerleşkeleri, kentsel gelişme eğilimlerini yönlendiren, modern gündelik hayatın gözde mekânları olmuştur. Barınma ve serbest zaman faaliyetlerini de kapsayacak şekilde tasarlanan fabrika yerleşkelerinin, yaşam biçiminin yenilenmesinde etkin olarak kullanılmış birer araç olduğunu söylemek mümkündür. Cumhuriyet dönemi sosyal fabrikalarını5, modern kimliğin inşasında başarılı olunmasının ancak yaşam biçiminin her alanda yenilenebilmesi ile özdeşleştirildiği mekânsal uygulamalar olarak ele almak gerekir. Dolayısıyla Anadolu'da kurulan endüstri yerleşkeleri, bir taraftan modern üretime geçmek, diğer taraftan modern kimlik ve toplumu inşa etmek amaciyla kullanılan bir araç olmuştur.

Türkiye'nin modernite projesi çerçevesinde uygulanan mekân politikaları, birey-yurttaş temelinde şekillenen toplumsal dönüşüm sürecinin yönlendirilmesinde etkin olarak kullanılmıştır. Ancak 1980'lerle başlayan süreçte sermayenin, ekonomik amaçları ve ihtiyaçları doğrultusunda kentsel mekânı dönüştürmesi, kentsel politikanın şekillendirilmesinde temel belirleyici olmuştur. Dolayısıyla 1980 sonrası mekân politikaları çerçevesinde, sermaye birikimi ve rant elde etmek amacıyla kentsel mekânların biçiminin, işlevinin ve algısının yeniden üretildiği ve yaşam biçiminin dönüştürüldüğü bir süreç

\footnotetext{
${ }^{5}$ Sosyal fabrika, kapitalist toplumsal ilişkilerin üretim alanı dışında bir bütün olarak tüm topluma nasıl yayıldığını analiz etmek için geliştirlmiş bir kavramdır. Bu konuda daha ayrıntılı bilgi için bkz. Tronti, 1962, s.9-12; Cengizkan, 2009.
} 
ortaya çımıştır. Bu bağlamda endüstri mirası da tarihsel, toplumsal ve kültürel değeri gözetilmeksizin çeşitli gerekçelerle kentsel değişim değeri ön planda tutularak, neoliberal kent politikaları kapsamında dönüşüme uğramiştır.

İdeolojik, ekonomik, yönetsel dönüşümlerle bağıntılı olarak 1996 yılından itibaren şeker rejiminin yeniden düzenlenmesine yönelik mevzuat değişiklikleri yapılmıştır. 2001 yılında 4634 sayılı Şeker Kanunu'nun yürürlüğe girmesi sonucunda uygulamada meydana gelen dönüşümler; şeker üretiminde ve arzında kota uygulanmasına geçilmesi, pancar ve şeker fiyatlarındaki serbesti sisteminin yürürlüğe girmesi ve Türkiye'de şeker sektörüne ilişkin tüm görevleri yerine getirmek üzere Şeker Kurumu'nun kurulması olarak sıralamak mümkündür. Kurumun karar organı olan Şeker Kurulu, şeker üretiminde arzı ve kotayı belirlemek başta olmak üzere, şeker piyasasını düzenleme ve denetleme yetkisine sahiptir. Şeker rejiminin yeniden düzenlenmesi ile eş zamanlı olarak 2000 yılında şeker fabrikaları yerleşkeleri ve taşınmazları özelleştirme kapsamına alınmış ve şeker fabrikası yerleşkelerinde mülkiyet ve fiziksel yapı dönüşümleri başlatılmıştır.

Endüstri mirası, "endüstriyel yapılar, kompleksleri, alanları ve endüstriyel peyzajın yanı sıra devam eden ya da geçmişteki üretim biçim ve sürecinin, hammadde çıkarımı ve ürüne dönüştürülmesinin ve ilgili enerji ve ulaşım altyapılarının kanıtları olan makine, obje, ve yapıları" kapsayan yerleşkeler olarak tanımlanmaktadır (TICCIH, 2011, s. 1). Dolayısıyla kültürel miras olarak endüstri mirasının korunması ve yönetimi, sadece yapı ve/veya nesne ile sınırlı değildir. Bu alanlar sahip oldukları çevre ilişkileri ile bir bütün olarak ele alınmalı ve incelenmelidir.

İnşa edildiği dönemin üretim biçimini ve teknolojisini yansıtan endüstri yapıları ve yerleşkeleri, bunun yanı sıra söz konusu dönemde toplumun sosyal, ekonomik, politik yapısını tanımlamaya da olanak sağlayan toplumsal belleğin taşıyıcısı niteliğindeki değerlerdir. Türkiye Cumhuriyeti'nin ilanı ile birlikte devlet yatırımlarıyla Anadolu' da endüstrileşme faaliyetlerinin hız kazandığı bilinmektedir. İlk kurulan üretim tesisleri ve yerleşkeleri, çoğunlukla şeker, tütün ve dokuma sanayi türlerinde olmuştur. Bu kapsamda, Uşak Şeker Fabrikası (1926), Alpullu Şeker Fabrikası (1926), Eskişehir Şeker Fabrikası (1933) ve Turhal Şeker Fabrikası (1934) ilk kurulan şeker fabrikalarıdır. Bu fabrikaları takiben 1951-1956 yıllarını kapsayan dönemde Malatya Şeker Fabrikası (1956) da dahil olmak üzere Anadolu'da toplam on bir yeni şeker fabrikası inşa edilmiştir. 1950 yılı sonrasında kurulan şeker fabrikaları ve yerleş- 
keleri modernleşme projesinin doğrudan ürünü olmamalarına karşın, kurulan ilk dört fabrika yerleşkesi ile benzer tasarım özelliklerine sahiptir. Söz konusu yerleşkeler, endüstri yapısının yanı sıra, işçi konutları, eğitim binaları, sosyal ve kültürel tesisleri de olan yerleşkeler niteliğindedir.

\section{Ulusal Modern Sanayinin Kuruluşu: Şeker Fabrikaları}

Cumhuriyetin sanayileşme sürecini, ekonomik, mekânsal ve toplumsal yeniden yapılanmayı kapsayan bütüncül bir politika olarak ele almak gerekmektedir. Yeni kurulan cumhuriyetin modernite projesi, ekonomik, teknolojik ve toplumsal yeniden yapılanma ve sanayileşme süreci ile birlikte mekân ile ilişkilendirilerek, mekânsal politikalar üzerinden gerçekleştirilmiştir. Bu kapsamda bir tüketim ihtiyacını karşılamak amacıyla kurulan Şeker Fabrikaları, birer yerleşke olarak tasarlanmaları ve kuruldukları kentlerde modern kimliğin ve toplumun inşası, kentleşme pratiğindeki yönlendirici etkisi gibi nedenlerle modernleşme projesinin önemli bir bileşeni olmuştur. 19. yüzyıldan itibaren endüstriyel bir ürüne dönüşen ve Osmanlı Devleti'nin en çok ithal ettiği ürünler arasında yer alan şeker, savaş yıllarında uluslararası ticaretin kesintiye uğraması nedeniyle temin edilemez bir hal almıştır. Yeni kurulan devletin milli ekonomi politikası, halkın temel tüketim maddelerinden biri olan şekerde dış devletlere olan ekonomik bağımlılığın sona erdirilmesini gerektirmekte idi (Karayaman, 2012, s. 56). Bu kapsamda, şeker pancarı üretimi ve şeker fabrikalarının kurulması öncelikli ekonomik politikalar arasında yer almıştır. 1923 yılında gerçekleştirilen İzmir İktisat Kongresi'nde şeker üretimi ve fabrikalaşma konusu ele alınmış ve 1925 yılında yürürlüğe giren 601 sayılı "Şeker Fabrikalarına Bahşolunan İmtiyaz ve Muafiyet Kanunu" ile şeker fabrikalarının kurulması teşvik edilmiştir. Bu gelişmeleri takiben ilk olarak 1926 yılında Uşak ve Alpullu Şeker Fabrikaları, 1933'de Eskişehir Şeker Fabrikası ve 1934'de Turhal Şeker Fabrikası kurulmuştur. Kurulan şeker fabrikaları, endüstri yapısının yanı sıra, işçi konutları, eğitim tesisleri, sosyal ve kültürel tesisleri de olan yerleşkelerdir. Bu nedenle şeker fabrikaları deneyimini, yalnızca üretim araçlarının modernizasyonu ve sanayileşme hareketi olarak adlandırmak eksik ve tek yönlü bir yorum olacaktır. Şeker fabrikalarının kuruldukları kentlerde yarattıkları iş imkanları, çağdaş barınma, eğitim ve sosyokültürel olanaklar ve kentin fiziki dokusuna etkisi olmasının yanı sıra, çağdaş mekânlar üzerinden geleneksel yaşam biçimi ve toplumsal kimlikler yerine modern kimlik ve yurttaş olma bilincinin oluşturulması gibi yaşam biçimlerinin oluşmasına da etkileri olmuştur. Bu bağlamda, inşa edildiği dönemin 
üretim biçimini ve teknolojisini bugüne aktaran endüstri yapıları ve donanımları, döneminin toplumsal sosyal, ekonomik ve politik yapısını tanımlayan kültürel miras olarak korunması gereken önemli değerlerdir.

Şeker üretim faaliyetleri, 1950 yılına kadar mevcut dört fabrikanın zaman zaman kapasitesi artırılarak sürdürülse de, her yıl artan şeker ihtiyacının tamamen yerli üretimle karşılanabilmesi için yeni fabrikaların kurulması zorunlu hale gelmiştir. 1951 yılında "Şeker Sanayii'nin Tevsi Programı" hazırlanmıştır. Program kapsamında 1951-1956 yıllarını kapsayan dönemde Anadolu'da Malatya Şeker Fabrikası da dahil olmak üzere toplam 11 yeni şeker fabrikası kurulmuştur.

1980 yılı sonrasında devletin ekonomi politikasının değişmesi ile modernleşme deneyiminin önemli bir aracı olarak değerlendirilen ve birer sosyal fabrika örneği şeklinde ele alınabilecek şeker fabrikaları hılı bir dönüşüm sürecine girmiştir. Bir başka ifadeyle, küresel ölçekte ekonomi politikaları çerçevesinde meydana gelen yeniden yapılanma, ulusal ölçekte ekonomik, toplumsal ve mekânsal bir dizi dönüşüm sürecini ortaya çıarmıştır. Neoliberal ekonomi politikalarının Türkiye'de şeker politikasına ilk etkisi, pancar alım fiyatlarının istikrarsızlaştırması sonucunda üretim kapasitesinde gerçekleşmiştir. İkinci etkisi ise 1996 yılından itibaren şeker rejiminin yeniden düzenlenmesine yönelik mevzuat değişiklikleridir. 19 Nisan 2001 tarihinde yürürlüğe giren 4634 sayılı Şeker Kanunu ve ilgili mevzuat ile uygulamada meydana gelen başlıca değişiklikler; şeker üretim ve arzında kota uygulanması, pancar ve şeker fiyatlarındaki serbesti sistemi ve Kanun kapsamındaki konularda sektörü düzenlemek ve denetlemekle Şeker Kurulu'nun yetkilendirilmesidir (TÜRKŞEKER, 2019, s.23). Şeker rejiminin yeniden düzenlenmesi ile eş zamanlı olarak şeker fabrikaları yerleşkeleri ve taşınmazları Özelleştirme Yüksek Kurulu'nun 20.12.2000 tarih ve 2000/92 sayılı Kararı ile Türkiye Şeker Fabrikaları A.Ş. (TÜRKŞEKER) özelleştirme kapsamına alınmıştır. Özelleştirme kapsamına alınması kararı, Anadolu'daki tüm şeker fabrikası yerleşkelerinin mevcudiyetini etkilemiştir. Şeker fabrikaları bu durumdan üç şekilde etkilenmiştir. Bir kısmı sadece arsalarının; bir kısmı arsa, taşınır ve/veya taşınmaz mülklerinin; bir kısmı ise tüm mülklerinin ve üretiminin özelleştirilmesi ile karşı karşıya kalmıştır. Bu çerçevede Malatya Şeker Fabrikası'nda kısmi bir dönüşüm ile başlayan süreç, üretim alanlarının dönüştürülmesini de kapsayan bir sonuç meydana getirmiştir. Malatya Şeker Fabrikası'nın geçirdiği dönüşüm de, üretim kapasitesinin düşürülmesi ve çalışan sayısının azaltılması ile başlamış, ardından mülkiyet devirleri ile devam etmiş, bunu takiben mekânsal yapının dönüşmesi ile sonlanmıştır. 


\section{Sanayisizleşme Çerçevesinde Şeker Fabrikalan}

1980 ve 1990'lı yıllar, kapitalist sistemde ekonomik istikrarın sağlanması için ekonomik hayata düzenleyici devlet müdahalesinin gerektiğini savunan Keynesyen ekonomi politikalarının sona erdiği ve tüm dünyada yeniden yapılanma sürecinin yaşandığı bir dönem olmuştur. Neoliberal politikaların egemenliğini pekiştirdiği özelleştirme ve sanayisizleşme süreçleri, mekânsal ve toplumsal dönüşümleri de zorunlu kılmıştır.

Toplam istihdam içinde sanayi sektörünün payının azalıp, hizmetler sektörünün payının artması gelişmiş Batı toplumlarında aynı süreçte yaşanmıştır. Gelişmiş ülkelerdeki sanayisizleşmenin temel nedeni, ekonomik etkinliklerin uluslararası hale gelmesi ve ulus devlet ekonomilerinin dünya pazarına açılması süreci ile ilişkili olarak küresel ekonominin yeniden yapılanmasıdır (Dicken, 1992). Söz konusu yeniden yapılanma süreci, birbiriyle ilişkili bir dizi gelişmeye neden olmuştur. Gelişmeler kapsamında sanayi sektöründe iki temel durum ortaya çımıştır. Bunlardan ilki, gelişmiş ülkelerde ileri teknoloji kullanılan yüksek verimlilikteki sanayi dallarında sermaye akışının hızlı bir şekilde artmasıdır. İkincisi, azgelişmiş ülkelerde üretilen benzer mallarla pazarda maliyet açısından rekabet edemeyen sanayi dallarının akıbetidir. Bu sanayi dalları, ya kapanmış, ya üretim faaliyetlerini üretim için gereken girdilerin daha ucuza sağlandığı coğrafyalara kaydırmış ya da kayıt dışı, düşük ücretli iş̧̧i istihdamı ile üretime devam etmiştir. Ekonomik yeniden yapılanma süreci, sanayi sektöründeki gelişmelere paralel olarak, hizmetler sektöründe istihdamın artması ile sonuçlanmıştır.

Mekânsal ve ekonomik yönleri olan sanayisizleşme süreci, sanayileşmiş ülkelerde Gayrisafi yurt içi hasıla (GSYIH) oranlarında sanayinin payı ve istihdam sayılarının sektörel değişimleri üzerinden açıklanırken, sanayileşme sürecinin tamamlanmadığı ülkelerde farklı şekillerde ortaya çıkmaktadır. Türkiye için ekonomik açıdan ele alındığında sanayileşmiş ülkelerde olduğu gibi bir sanayisizleşme hareketinden söz edilemez. Ancak mekânsal dönüşüm açısından bakıldığında, sanayinin merkezden çepere doğru yer değiştirmesi (decentralization), sanayinin yer değiştirmesi (relocation) ve sanayi alanının/yerleşkesinin yeni bir fonksiyon kazanması (de-industrialization) olarak tanımlamak mümkündür (Ayik ve Avc1, 2018, s. 1279). Bu çerçevede, Türkiye'de GSYİH ve istihdamın sektörel yapısında meydana gelen dönüşümler gibi makro göstergelerden çok, büyük ve orta ölçekli kentlerde, kentsel değişim değerinin yüksek olması nedeniyle kent merkezlerindeki sanayi alanlarının dönüşümü üzerinden bir sanayisizleşmeden söz edilebilir. Türkiye'de 
1980 sonrası uygulanan ekonomi politikaları çerçevesinde kalkınmanın finans, inşaat ve hizmet sektörlerine dayalı olarak gerçekleştirilmesi, kentsel mekânı sermaye için yatırım alanına dönüştürmektedir. Sermaye birikimi ve rant elde etmek amaciyla kentsel mekânların biçiminin, işlevinin ve algısının yeniden üretilerek yaşam biçiminin de dönüştürüldüğü projeler olarak kentsel dönüşüm uygulamaları kentin farklı alanlarına odaklanmaktadır. Bu bağlamda endüstri mirası ve kültürel miras olarak değerlendirilebilecek endüstri yerleşkelerinin işlevsel, fiziksel ve mülkiyet yapısı da, tarihsel, toplumsal ve kültürel değeri gözetilmeksizin çeşitli gerekçelerle değişim değeri ön planda tutularak neoliberal kent politikaları kapsamında dönüştürülmektedir. Sanayi üretimininin yerini inşaat ve finans sektörlerinin alması, işlevini yitiren ve mevcut arazi kullanımında kent merkezinde kalan sanayi alanlarının dönüşüm sürecini hızlandırmıştır. Bir başka ifadeyle, üretimin yerini alan inşaat ve finans sektörleri, işlevini yitirdikleri veya kent içindeki atıl alanlar oldukları gibi gerekçelerle kamu mülkiyetinde olan endüstri alanlarına yönelmiştir.

\section{Endüstri Mirası Olarak Şeker Fabrikası Yerleşkeleri}

Endüstri arkeolojisi kavramı, eski endüstri yapılarının araştırılması, saptanması ve kayıt altına alınması işlemlerinin bütününü kapsayan genel bir kavramdır. Mimarlık tarihi, teknoloji tarihi, arkeoloji ve koruma boyutları olan endüstri arkeolojisi disiplini 1950'lerde ortaya çıkmıştır (Föhl, 1995). Falser, endüstri mirasının, sadece fabrika ve imalathanelerden oluşmadığını, aynı zamanda kanallar, demiryolları, köprüler, ulaşım araçları, güç kaynakları ve işletme yerleşkeleri gibi yeni teknolojilerle üretilen sosyal ve teknoloji zaferlerini de kapsamakta olduğunu belirtmektedir (Falser, 2001, s.9). 2003 yılında gerçekleştirilen Uluslararası Endüstri Mirasını Koruma Komitesi (The International Committee of the Conservation of Industrial Heritage, TICCIH) toplantısında kabul edilen Nizhny Tagil Sanayi Mirası Şartı'nda (The TICCIH Nizhny Tagil Charter for the Industrial Heritage), endüstri mirası kavramı, "tarihsel, teknolojik, sosyal, mimari veya bilimsel değere sahip olan sanayi kültürünün kalıntıları" olarak tanımlanmaktadır. Bu kalıntılara; "binalar, makine ekipmanları, atölyeler, imalathaneler ve fabrikalar, arıtma ve işleme alanları, maden ocakları, antrepolar ve depolar, enerji üretim alanları, altyapı ve ulaşım bağlantıları, endüstriyel dönemde çalışanların yaşadıkları evler, eğitim birimleri, sosyal alanlar ve dini yapılar" girmektedir (TICCIH, 2003, 2011). 
Endüstri mirasının korunması konusunda faaliyet gösteren bir diğer uluslararası organizasyon olan Uluslararası Anitlar ve Sitler Konseyi (International Council on Monuments and Sites, ICOMOS), tarihi antlar ve sitlerin korunması ve değerlendirilmesine yönelik araştırmaları desteklemek ve yönlendirmek, koruma kapsamında ilkeler, teknikler ve siyasetler geliştirmek amacıyla 1965 yılında kurulmuştur. 2011 yılında Uluslararası Endüstri Mirasını Koruma Komitesi'nin (TICCIH) de katılımıyla düzenlenen ICOMOS 17. Genel Kurulu'nda yeniden ele alınan ve Dublin İlkeleri (The Dublin Principles) olarak bilinen Endüstriyel Miras Alanları, Yapıları ve Peyzajını Koruma İlkeleri'ne göre (Principles for the Conservation of Industrial Heritage Sites, Structures, Areas and Landscapes) endüstri mirası, "endüstriyel yapıları, kompleksleri, alanları ve endüstriyel peyzajin yanı sıra devam eden ya da geçmişteki üretim biçim ve sürecinin, hammadde çıkarımı ve ürüne dönüştürülmesinin ve ilgili enerji ve ulaşım altyapılarının kanıtları olan makine, obje ve yapıları kapsar" olarak tanımlanmıştır (ICOMOS, 2011).

Türkiye'de koruma konusundaki temel hukuki belge, 1983 yılında yürürlüğe giren 2863 sayılı Kültür ve Tabiat Varlıklarını Koruma Kanunu'dur. Kanun, kültür varlıklarını, "tarih öncesi ve tarihi devirlere ait bilim, kültür, din ve güzel sanatlarla ilgili bulunan veya tarih öncesi ya da tarihi devirlerde sosyal yaşama konu olmuş bilimsel ve kültürel açıdan özgün değer taşıyan taşınır ve taşınmazlar" olarak tanımlamaktadır. Korunması gerekli taşınmaz kültür ve tabiat varlıklarının belirtildiği Kanun'un 6. maddesinde "19. yüzyıl sonuna kadar yapılmış taşınmazlar, belirlenen tarihten sonra yapılmış olup önem ve özellikleri bakımından Kültür ve Turizm Bakanlığı'nca korunmalarında gerek görülen taşınmazlar, sit alanı içinde bulunan taşınmazlar" olarak ifade edilmektedir. Gültekin (2016), "kanunda yer alan tanımlamalarda endüstri yapı ve yerleşkelerinin kültür varlığı örneği olarak anılmamasına, bu alanların kültür mirası olmadığı kararlarının verilmesine ve böylece bu değerlerin kaybedilmesine neden olduğu" hususuna dikkat çekmektedir.

Endüstri mirasını, endüstri kültürünün tarihsel, teknolojik, toplumsal, mimari ya da bilimsel değeri bulunan binaları ve makineleri, atölyeleri, imalathaneleri ve fabrikaları, madenleri ve işleme ve arıtma alanlarını, ambarları ve depoları, enerjinin üretildiği, iletildiği ve kullanıldığı yerleri, taşımacılığı ve tüm altyapısını, ayrıca barınma, ibadet ve eğitim gibi endüstri ile ilişkili toplumsal etkinlikler için kullanılan yerleri içeren yerleşkeler olarak ifade etmek mümkündür. Bu kapsamda, endüstri mirası olarak nitelendirilen yapı ve yerleşkelerin uluslararası miras kapsamında kabul edilmesinin temel nedeni, bulundukları ülkenin ve kullanıldıkları dönemin teknolojik, ekonomik, 
mekânsal, toplumsal yapısının tarihsel ve kültürel göstergeleri olarak kabul edilmesi ile ilişkilidir. Bu durum, kültürel mirasın bir bileşeni olarak endüstri mirasının dünya mirası statüsünde kabul görmesine ve korunmasına olanak sağlamaktadır. Uluslararası platformlar aracılığıyla gelişen araştırma, analiz ve koruma yaklaşımları, ulusal düzeyde endüstri mirasının korunması çabalarına da etki etmiş̧ir. Ancak Türkiye'de endüstri mirası kavramının, ilgili mevzuatta açık olarak tanımlanmaması ve yer almaması, bu alanlar için koruma kararlarını alınmasında yönlendirici olmakta ve bu alanların kültür mirası olarak kabul edilmemesi sonuçlarını ortaya çıkarmaktadır.

\section{Geçmişten Günümüze Malatya Şeker Fabrikası Yerleşkesi}

1928 yılında Malatya Elektrik Santrali'nin kurulması, 1931 yılı başlarında Malatya'yı Adana'ya bağlayan demiryolunun tamamlanması ve ardından 1937 yılında Sivas Malatya Demiryolu hattının faaliyete başlaması ile modern devletin yeni mekânsal odaklarından biri olarak tasarlanan Malatya'da, sanayi yatırımları için gerekli öncelikli altyapı tamamlanmıştır. Malatya'da devletin gerçekleştirdiği ilk üretim sanayi yatırımları, 1936 yılında inşasına başlanan Sümerbank İplik ve Bez Dokuma Fabrikası ile Malatya Sigara Fabrikası olmuştur. Bu sanayi yatırımlarını takiben, "Şeker Sanayii'nin Tevsi Programı" kapsamında Anadolu'da kurulması öngörülen on bir yeni şeker fabrikasından biri olarak yatırım kararı 1951 yılında alınan Malatya Şeker Fabrikası 1956 yılında üretime başlamıştır.

Malatya-Ankara karayolu üzerinde bulunan Malatya Şeker Fabrikası, bugünkü kent merkezine 5 km, Malatya Tren Garı'na 200 m uzaklıktadır. Yerleşke, doğuda Devlet Demiryolları (DDY) Lojmanları, batıda Malatya Güney Çevreyolu Caddesi, kuzeyde Malatya-Ankara Karayolu, güneyde ise Malatya Tren Garı ve askeri alan ile sınırlanmaktadır (Şekil 1). Yerleşke, kurulduğu dönemdeki yerleşik alanların batı/güneybatısında yer almakta iken günümüzde konut alanları içinde kalmıştır. 


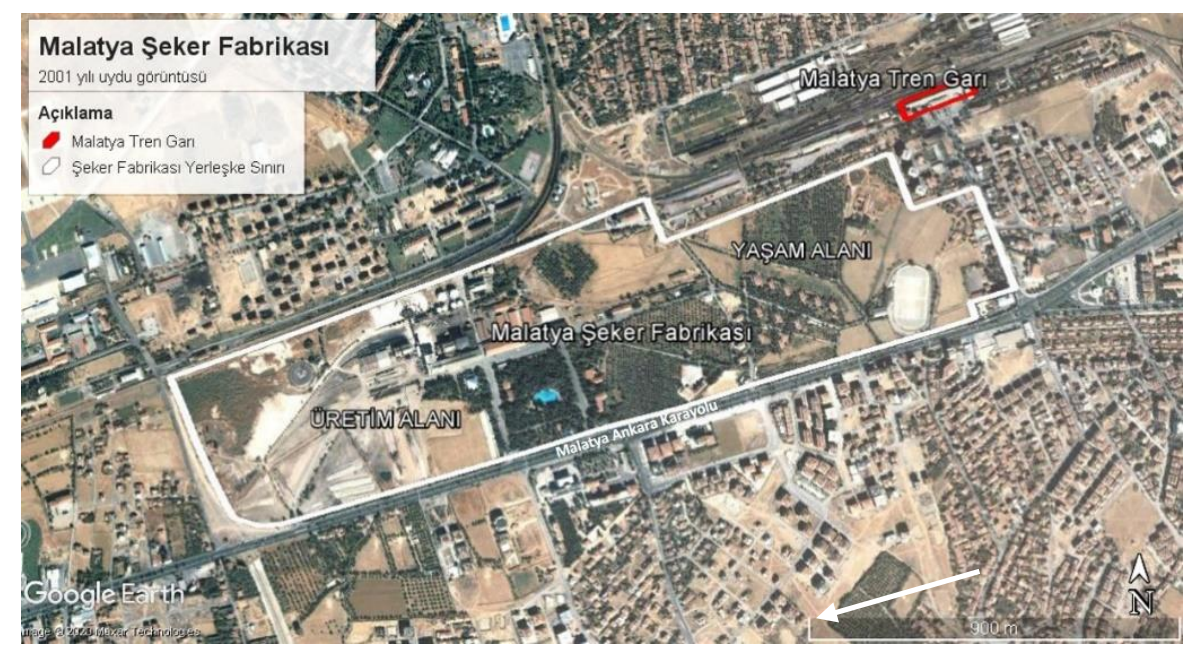

Şekil 1. Malatya Şeker Fabrikası'nın Konumu (Kaynak: https://earth.google.com)

Kurulduğu dönemde, Malatya Şeker Fabrikası Yerleşkesi içinde yer alan yapıları; şeker fabrikası ile şeker üretim sürecinde kullanılan pancar depolama alanı, ambarlar, silolar, durultma havuzu, küspe kurutma ve alkol fabrikası gibi üretim yapıları, işletme, muhasebe, yönetim gibi ofis binaları, garajlar, yollar gibi servis yapı ve alanları olarak sıralamak mümkündür.

Yemekhane, cami, ilkokul, park, tenis kortları, basketbol, futbol ve voleybol sahaları, stat, lokal, misafirhane, lojman gibi sosyal aktivite, barınma, spor ve eğitim alanları yerleşke içinde yer alması ise, Malatya Şeker Fabrikası Yerleşkesinin bir yaşam alanı olarak tasarlandığını göstermektedir. Kurulduğu dönemde var olan bu işlevsel kullanımlar, yerleşke içinde üretim tesisleri ve yaşam alanı olmak üzere 2 farklı kampüs şeklinde (Şekil 1) mekânsal olarak ayrıştırılmıştır. Camii, yemekhane ve spor tesislerinin bir kısmı üretim tesislerinin yer aldığı üretim kampüsünde; eğitim, işçi ve memur lojmanları, misafirhane ve lokal kullanımları ise yerleşkenin doğu kısmındaki kampüste yer almaktadır. Malatya, Cumhuriyet dönemi kentleşme politikasının Anadolu'daki öncelikli uygulama alanlarından biri olmuştur. Kentin yerleşik alanlarının dışında, demiryolu bağlantısına yakın mesafede bir sanayi bölgesinin kurulması, oluşturulan sanayi yerleşkelerinin sosyal ve kültürel aktiviteler ile bir bütün olarak planlanması, Cumhuriyet ideolojisinin Anadolu'nun imarında başvurduğu temel yöntemdir. Bu dönemde planlanan endüstri yerleşkeleri, üretim sistemi, ekonomik ve toplumsal yapıda yaşanan modernleşme sürecinin mekân politikasına entegre edildiği örneklerdir. 
Fabrika, çağın gerektirdiği modern üretim teknolojisi ve araçlarının kullanıldığı endüstriyel üretim tesisi olarak sınai üretim sisteminin temsili olmasının yanı sıra, tarımsal üretime dayalı ekonomik yapıdan sanayi üretimine dayalı kapitalist ekonomik ve toplumsal yapıya geçişin de fiziki ve mekânsal temsilidir. Bu nedenle, işgücüne yönelik eğitim ve sosyal aktivite alanlarının çalışma alanı yakınında bir yerleşke içinde emeğe sunulması hem modernleşme deneyiminin gereği uygulamalardan birisi olarak değerlendirilmesine, hem de refah devleti anlayışı çerçevesinde gerçekleştirilen uygulamalar olarak ele alınabilmesine olanak sağlamaktadır.

TÜRKŞEKER'in özelleştirme kapsamına alınmasından yaklaşık 5 yıl sonra Malatya Şeker Fabrikası Yerleşkesi'nde de diğer fabrikalarda olduğu gibi özelleştirme süreci fiilen başlatılmıştır (bkz. Ek 1). Bu kapsamda, toplam 98,8 hektarlık yerleşke alanının 2005/73 sayılı Özelleştirme Yüksek Kararı ile doğrudan şeker üretimi için gerekli birimlerin olduğu 19,8 hektarlık bölümü TÜRKŞEKER'e bırakılarak, geri kalan bölümü özelleştirme programına alınmiştır.

2005 yılına kadar tek bir parsel (1072 ada ve 15 no.lu) olan Şeker Fabrikası Yerleşkesi, 2006/62 sayılı Özelleştirme Kararı sonucunda ifraz işlemleri ve kararda ayrıca tanımlanmış alan kullanımı kararlarına uyulması koşuluyla Malatya Belediye Başkanlığına devredilmiştir. İfraz sonrasında oluşturulan parseller (1072 ada 19, 21 ve 22 no.lu parseller) için imar planında "spor kompleksleri, arboretum, su oyun ve gösteri alanları, suni gölet, aquapark, amfi tiyatro, halka hizmet verebilecek muhtelif aktivite alanları, sosyal tesisler, yerel ürünlerin tanıtımını temin edebilecek teşhir ve buluşma merkezleri ile diğer peyzaj donatıları gibi" kullanımlar belirlenmiştir.

Söz konusu taşınmazların ada-parsel numaraları Şekil 2' de ve bugünkü kullanım alanları Şekil 3'te gösterilmiştir. Buna göre, 1072/22 no.lu parselin Belediye Yaşam ve Spor Merkezi, kafeterya ve tenis kortlarından oluşan bir kullanım alanına dönüştüğü, 1072/21 no.lu parselin fiziksel ve işlevsel dönüşümünün tamamlanmamış olduğu görülmektedir. 1072/20 no.lu parselde bulunan Şeker Camii, ibadet tesisi işlevi devam etmekle birlikte Diyanet İşleri Başkanlığı'na tahsis edilmek üzere, Maliye Hazinesi'ne devredilmiştir. 


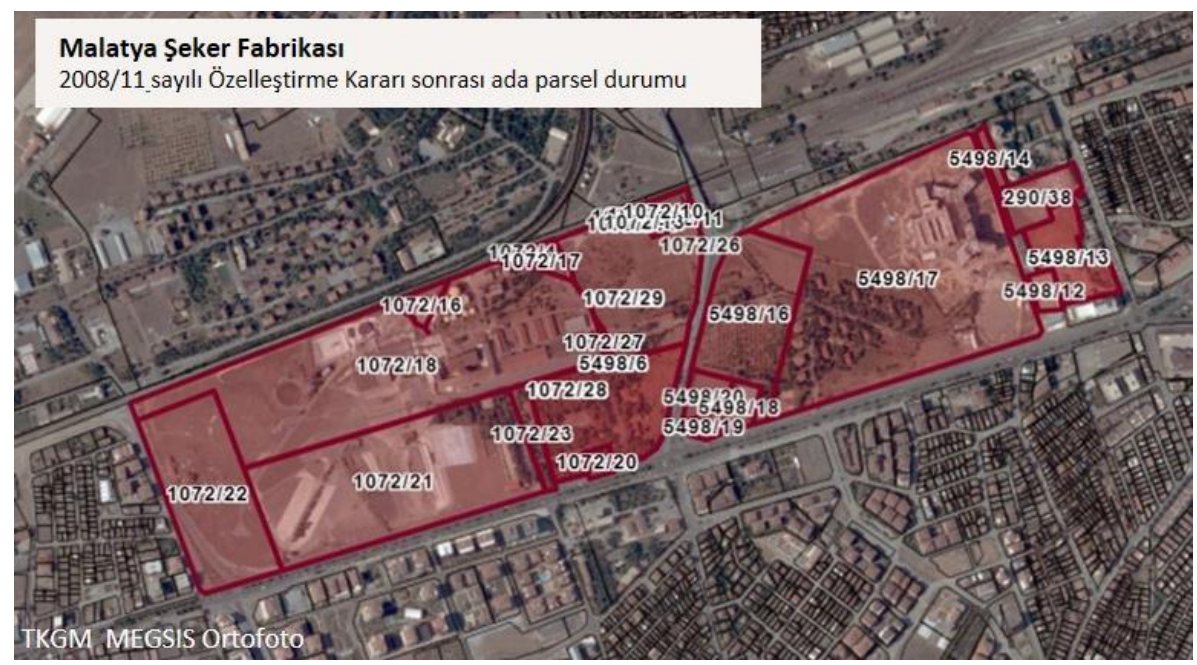

Şekil 2. Özelleştirmeler sonrası Malatya Şeker Fabrikası Yerleşkesi Ada ve Parsel Durumu (Kaynak: https://earth.google.com ve https://parselsorgu.tkgm.gov.tr/ adreslerinden elde edilen görüntülerden yararlanılarak hazırlanmıştır)

2006/90 say1l karar ile 290/38 no.lu ada6, "Emniyet Hizmetlerinde" kullanılmak üzere İçişleri Bakanlığı Emniyet Genel Müdürlüğü'ne devredilmiş ve güncel arazi kullanımına göre yapılaşmış durumdadır.

2008/11 sayılı karar ile 15498/17 no.lu ada7 "Hastane ve Sağlık Kampüsü “ yapımı amacıyla Sağlık Bakanlığı'na tahsis edilmiş ve bu alanda güncel arazi kullanımına göre inşa edilen hastane hizmet vermeye başlamıştır. Adada yer alan Şeker Lojmanları, güncel arazi kullanımında aynı işlev ve fiziki yapıda varlığını sürdürmektedir.

Yine 2008/11 sayılı karar ile mevcut ada parsel numaraları ilan edilmemiş olmakla birlikte ilk ifrazdan önceki 1072/19 no.lu parselden yaklaşık 65.000 metrekare alan, "Spor Tesisi" yapılmak üzere Başbakanlık Gençlik ve Spor Genel Müdürlüğ̈̈̈'ne tahsis edilmek üzere Maliye Hazinesi'ne devredilmiştir. Aynı karar ile 5498/18 no.lu parselde bulunan Şeker İlköğretim Okulu, yeni bir okul yapılıp hizmete girinceye kadar kullanılması amacıyla İl Milli Eğitim Müdürlügü̈'ne tahsis edilmiştir.

Özelleştirmeler sonucunda şeker fabrikası yerleşkesi (Şekil 2), üretim işlevi dışında kurulduğu dönemde barındırdığı işlevlerin büyük bölümünü yitirmiş ve yerleşke parçalar halinde çeşitli devlet kurumlarına devredilmiştir.

\footnotetext{
${ }^{6} 290$ ada 19 ve 28 no'lu parsellerden toplam $7.000 \mathrm{~m} 2$ 'lik alanın ifraz edilmesinden sonra elde edilen alan. 71072 ada 19 no.lu parselden yaklaşık $23.000 \mathrm{~m} 2$ alan ile 291 ada 14 no.lu parselde bulunan hisse ile birlikte toplam $200.000 \mathrm{~m} 2$ 'lik alanın hakları karşılığında tahsis edildiği alan.
} 
Şeker Fabrikası Yerleşkesi içinde yer alan ispirto fabrikası, kurulduğu dönemden günümüze şeker fabrikası yerleşkelerinde yer alan 4 ve özelleştirmeler sonrasında TÜRKŞEKER A.Ş. mülkiyetinde kalan 2 alkol fabrikasından birisidir. Ticari değere sahip etil alkol, büyük oranda şeker üretim sürecinin bir yan maddesi olan "melas"tan üretilmektedir. Silah sanayinde, ilaç, kozmetik ve parfümeride kullanılmak üzere Malatya Alkol (İspirto) Fabrikası'ndaki etil alkol üretimi, arıtma tesisinin olmaması gerekçesiyle 2004 y1lında son bulmuştur. Malatya Alkol Fabrikası'nın kapatılmasından sonra, yerleşkesinde yalnızca şeker üretimi işlevi devam etmektedir.

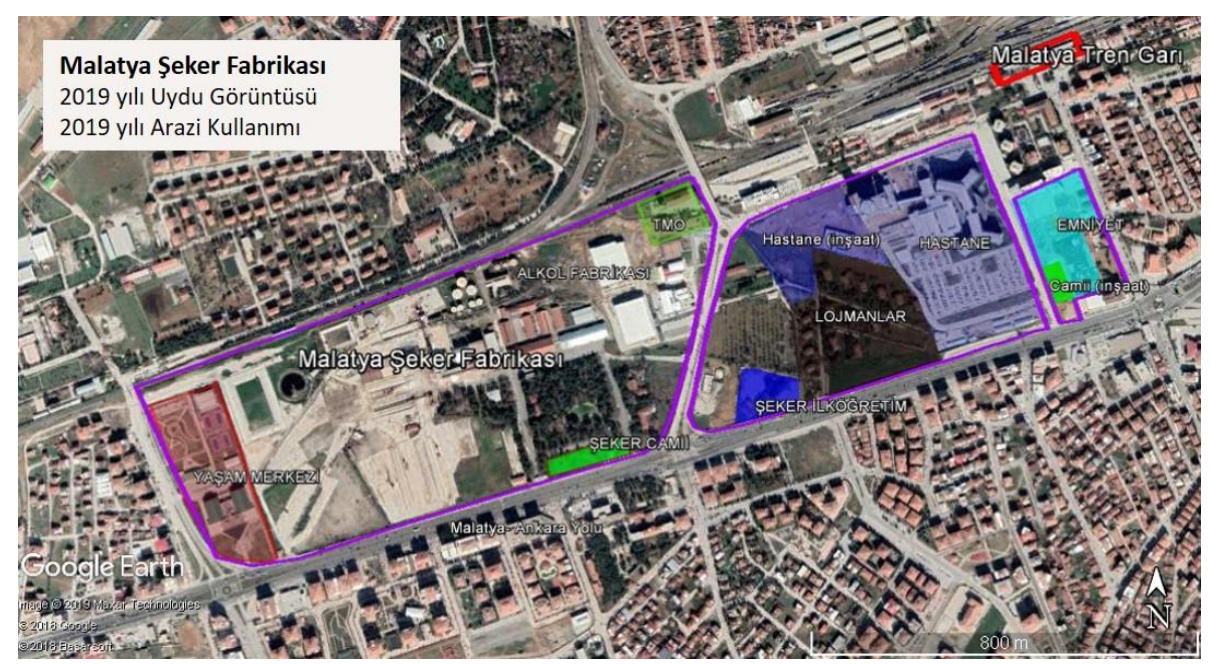

Şekil 3. Özelleştirmeler sonrası Malatya Şeker Fabrikası Yerleşkesi Arazi Kullanımı (Kaynak: https://earth.google.com adresinden elde edilen uydu görüntüsünden yararlanilarak hazırlanmıştır)

Özelleştirme sonrası, kurulduğu dönemdeki işlevsel kullanımları değişen bu alanlarının mülkiyetinin farklı kurumlara devredilmesi sonucunda yerleşkenin güncel arazi kullanım durumu Şekil 3'te gösterilmektedir. Yaşam Merkezi olarak gösterilen alan Malatya Büyükşehir Belediyesi'ne devredilmiş ve spor kompleksi olarak yeniden üretilmiştir. Aynı özelleştirme kararı ile kuruluşundan günümüze ibadethane işlevinde bulunan Şeker Camii'nin sadece mülkiyet durumu değiştirilerek Diyanet İşleri Başkanlığı'na devredilmiştir.

2008 yılında alınan özelleştirme kararı sonucunda mülkiyeti Sağlık Bakanlığı'na devredilerek Şekil 3'te görüldüğü hali ile hastane olarak dönüştürülen alanda, fabrikanın kurulduğu dönemde Şeker Stadı'nın bulunduğu bilinmektedir. Şeker İlkokulu ise, özelleştirmeler sonrasında fiziki bir değişikliğe 
uğramamış olsa da, bölgede yeni bir okul yapılana kadar mevcut halini koruyacağı kararlaştırılmıştır. Ancak yeni okulun inşaatından sonra bu alanın dönüştürülmek üzere Malatya Büyükşehir Belediyesi'ne devredilmesi şeklinde bir mülkiyet dönüşüm kararı bulunmaktadır. Özelleştirmeler öncesi arazi kullanımı ile uydu görüntülerinin karşılaştırılması (Şekil 4), mülkiyet dönüşümlerini takiben yerleşkede hızlı bir yapılaşma süreci yaşandığını göstermektedir.

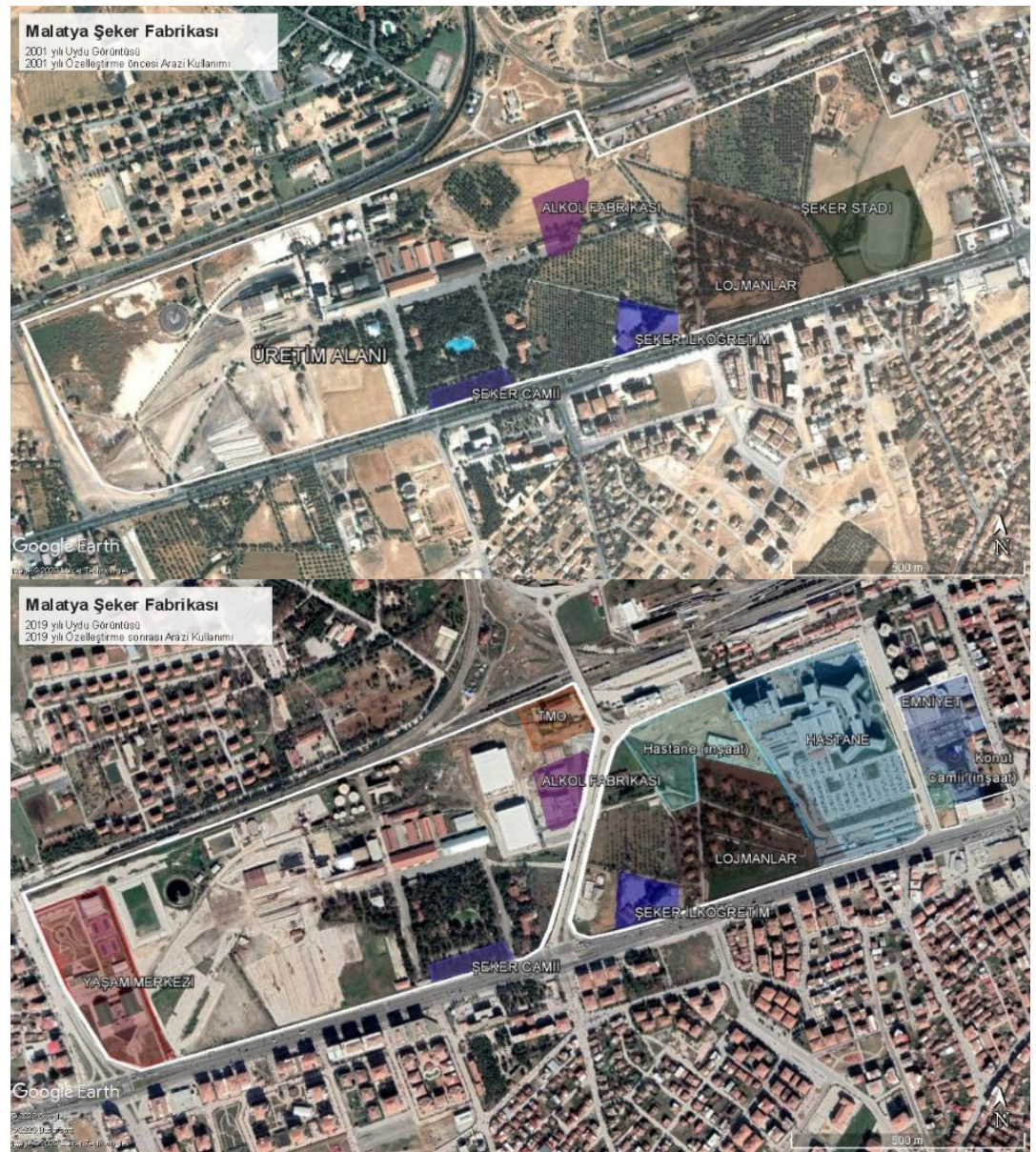

Şekil 4. Malatya Şeker Fabrikası Yerleşkesi 2001 ve 2019 yılları Arazi Kullanımı Karşılaştırması (Kaynak: https://earth.google.com)

Neoliberal sürecin ekonomik ve mekânsal politikalarının yeni kent merkezlerinde "rant değerli" konumda yer alan yerleşkeleri dönüştürmesine yö- 
nelik uygulamları, 1990 sonrası süreçte üretim kapasitesi düşürülen, çalışanları işten çıkarılan ve özelleştirmeye uğrayan Malatya Şeker Fabrikası örneğinde (Şekil 3 ve Şekil 4) doğrudan görülebilmektedir. Yerleşkenin kullanım değeri yerine değişim değerinin önem kazanması, egemen ekonomi-politik ideolojinin bir gereği olarak kabul görmektedir. Ancak modernleşme deneyimi çerçevesinde Malatya'nın imarında önemli bir dinamik olarak tasarlanan sanayi koridorunun bir uzantısı olması ve farklı bir ekonomi-politik süreçte kurulmuş olmasına karşın, modernite deneyimi çerçevesinde inşa edilen sanayi yerleşkeleri ile benzer tasarım özellikleri taşıması, sanayi koridorundan günümüze ulaşan tek üretim tesisi olması, kolektif belleğin önemli bir bileşeni kabul edilmesi ve döneminin üretim, teknoloji ve toplum yapısını yansıtması itibari ile gelecek kuşaklara aktarılması gereken değerlerden biri olduğu yadsınamaz bir gerçektir. Sosyal fabrika olarak ele alınabilecek özellikler taşıyan Fabrika, bir kampüs olarak tasarlanmıştır.

Özelleştirmeler sonucunda, işlev ve arazi yapısı çerçevesinde orijinal dokusunu kaybetmiş olmasına karşın, Fabrika'nın temel üretim binası Sivas Kültür Varlıklarını Koruma Bölge Kurulu'nun 31 Mayıs 2018 tarihli 4357 no.lu kararı ile 1. grup yapı olarak tescillenmiştir. Taşınmaz Kültür Varlıklarının Gruplandırılması, Bakım ve Onarımları hakkında 660 sayılı İlke Kararı'na göre, 1 . grup yapı, "toplumun maddi tarihini oluşturan kültür verileri içinde tarihsel, simgesel, anı ve estetik nitelikleriyle korunması zorunlu yapılar" olarak tanımlanmaktadır. Geç kalınmış bir karar olmasına karşın, fabrikanın elde kalan sınırlı endüstri mirasının korunması açısından olumlu kabul edilebilir.

\section{Sonuç Yerine: Malatya Şeker Fabrikası Yerleşkesini Bir Endüstri Mirası Olarak Tanımlama ve Koruma Gereği}

Cumhuriyetin kurucu ideolojisinin bölgesel gelişme odaklarından biri olarak devletin sanayi yatırımlarını gerçekleştirdiği Malatya ilinde, Tren Garı'nın güneyinde demiryolu bağlantısına yakın Sümerbank İplik ve Bez Dokuma Fabrikası (1936), Malatya Sigara Fabrikası (1936) ve Malatya Şeker Fabrikası'nın (1956) kurulduğu bölgeyi bir sanayi aksı olarak tanımlamak mümkündür. Malatya ili sanayi aksından günümüze ulaşan tek endüstri yerleşkesinin Malatya Şeker Fabrikası olduğunu belirtmek gerekir.

Cumhuriyet döneminde kurulan şeker fabrikası yerleşkelerinin bulundukları kentler öncelikli olmak üzere, Anadolu'da sanayinin gelişmesinde, 
ekonomik ve toplumsal kalkınmasında ve modernleşme deneyiminin başarısında önemli bir yere sahip olduğu bilinmektedir. Bu kapsamda yerleşkenin önemi, Malatya'nın modernleşme öyküsünün yanı sıra, ulusun modernleşme sürecinin bir parçası olması ile birlikte ele alınmalıdır. Nitekim bu çerçevede geç kalınmış olsa da, Fransız yapımı olan Malatya Şeker Fabrikası Yapısı, Sivas Kültür Varlıklarını Koruma Bölge Kurulu'nun 31 Mayıs 2018 tarihli 4357 no.lu kararı ile Kültür Varlığı olarak tescil edilmiştir. Aynı yıl içerisinde yerleşkeye ilişkin diğer bir koruma kararı da lojmanlar için alınmıştır. Bu kapsamda, mülkiyeti Maliye Hazinesi'ne ait olarak tapuda 5498 ada ve 17 no.lu parselde kayıtlı bulunan Şeker Fabrikası Lojmanı'nda yer alan 2-4-6-89-10-11-13-15-17-19 plan numaralı binalar, Koruma Bölge Kurulu'nun 01 Aralık 2018 tarih 4811 no.lu kararı ile 2. grup olarak tescil edilmiştir. Ancak Kültür ve Turizm Bakanlığı Kültür Varlıklarını Koruma Yüksek Kurulu'nun 19 Haziran 2019 tarih ve 1221 no.lu kararı ile lojman binalarının tescilleri kaldırılmıştır. Söz konusu iptal kararı sürecinin, özelleştirme sürecinde olan Şeker Fabrikaları A.Ş. Genel Müdürlüğü'nün başvurusu üzerine başlatılmış olması, "yapılacak kamu yatırımları göz önünde bulundurulduğundan" ibaresinin kararda yer alması gibi somut nedenler (Altaş, 2020, s. 2; Hazar, 2019, s. 1), neoliberal politikaların özelleştirme ve sanayisizleşme gibi etkileri ve ekonomik rant odaklı kentsel politikalar çerçevesinde koruma kararlarının da değiştirilebildiğini göstermekte ve kültürel miras alanlarının korunması için bu kararların alınmış olmasının yeterli olup olmadığı sorusunu tekrar gündeme getirmektedir. Yerleşkeye yönelik koruma karalarının değişmesi, lojman yapılarının tescil kararının iptal edilmesi sürecinde olduğu gibi, fabrika yapısı hakkındaki tescil kararının da Yüksek Kurul'a götürülmesi ve kurulun kararı bozabilme ihtimali olduğuna dair söylentileri (Erbaş, 2019, s.2) güçlendirmektedir.

1980 sonrası uygulanan neoliberal politikalar, yeni kentsel alanların yaratılması ve sermayenin ihtiyaçlarının karşılanması amacıyla kentsel mekânın yeniden şekillendirilmesini zorunlu kılmıştır. Bu kapsamda, sanayileşen alanlarda üretim işlevinin devam ettirilmesi yerine, yeni işlevler verilerek daha fazla kâr getiren kullanımlara dönüştürülmüştür. Ancak sanayi alanlarına yapılan mekânsal müdahale, alan kullanım kararının değiştirmesiyle s1nırlı kalmamıştır. Bir taraftan fabrika yerleşkelerinde işlev değişikliği ile bağıntılı olarak meydana gelen fiziki yapı dönüşümleri ve diğer taraftan özelleştirme kapsamında gerçekleştirilen mülkiyet dönüşümleri mekânsal müdahalenin diğer boyutları olmuştur. Malatya Şeker Fabrikası örnekleminde şe- 
ker rejiminde yapılan ulusal ölçekli değişiklikler, üretim kapasitesinin düşürülmesi ve çalışan sayısının azaltılması gibi doğrudan üretim işlevine yönelik değişikliklerle başlamış, yine ulusal ölçekte meydana gelen özelleştirme hareketleri yerleşkenin parça parça farklı kurumlara mülkiyet devrinin yapılması şeklinde yansımıştır. Tüm bu dönüşümlerin nihai sonucu, yerleşkenin fiziki yapısında dönüşümler yapılarak orijinal dokusunun kaybedilmesi olmuştur. Bu durum, korunması gerekli alanlar olarak endüstri mirasını, aslında üretim işlevlerindeki dönüşümlerle başlayan bir korunamama sürecine götürdügüüü bir kez daha göstermiştir. Dolayısıyla söz konusu alanların yalnızca koruma statüsü kazandırılması ile korunabileceği düşüncesinin de sorgulanması gereğini tekrar gündeme getirmiştir.

Türkiye'de koruma statüleri konusunda bir diğer husus ise korumaya ilişkin mevzuatta endüstri mirası kavramının, açık olarak tanımlanmaması ve yer almamasıdır. Tanımlamaya yönelik söz konusu eksiklik, gerek genel anlamda tüm endüstri alanlarında, gerekse Malatya Şeker Fabrikası özelinde çoğu zaman endüstri alanlarının kültür mirası olarak değerlendirilmesi ve alana ilişkin koruma kararlarının alınmasında olumsuz sonuçlara neden olmaktadır. Bir başka ifadeyle söz konusu endüstri alanlarının kültürel miras olarak kabul edilmemesi sonucunu ortaya çıkarmaktadır. Ancak örneklem özelinde, mevzuattaki söz konusu eksiklik veya alanın büyük bir kısmının orijinal dokusunu kaybetmiş olması gibi durumların, koruma kararının alınmasında olumsuz bir belirleyiciliği bulunmamaktadır. 


\section{Extended Abstract}

\section{Conservation and Transformation of Industrial Heritage: The Case of Malatya Sugar Factory Campus}

\author{
Fahriye Yavaşoğlu \\ ORCID: 0000-0003-0771-237X
}

\author{
Can Giray Özgül \\ ORCID: 0000-0001-8569-6518
}

Modernity, which emerged from the 17th century and defined as a way of social life and organization in Europe, is addressed in four basic dimensions: individual, social, institutional and economic. In societies outside of Europe, modernity has occurred as a spontaneous process of change within the framework of the functioning of capitalism or implemented using reformist institutional arrangement. Space policies implemented within the framework of Turkey's modernity project have been used effectively in directing the social transformation process shaped on the basis of individual-citizen. In other words, he modernity project of the newly established Republic has been implemented in conjunction with spatial policies, associating it with space through economic, technological and social policies.

It can be said that the factories are established primarily to supply the needs of consumption and commence modern production, reproduced by individuals and society, designed and established as a campus/living area. The factory campuses, which are known to affect urbanization practice in their establishment, have been popular places in modern daily life, guiding urban development tendencies. It is possible to say that factory campuses designed to include accommodation and leisure time activities are effectively used as tools for the renewal of lifestyle. However, in the process that started in the 1980s due to neo-liberal policies, it has created a process in which space policies are transformed in coordination with the transformation of economic and political structure. These transformation have enabled capital to transform urban space in accordance with economic purposes and needs, and to have central position in formalize urban policy. Therefore, post 1980, the space policies were carried out 
through applications where the form, function and perception of urban spaces were reproduced and the lifestyle was transformed and the space was handled with a fragmentive approach in order to obtain capital accumulation and rant. Factory campuses, one of the spatial applications of the Republic's modernity project, which have been used effectively, have been transformed in related with the transformation of urban policies. However, the industrial structures and campuses reflecting the production style and technology of the period they were founded are also cultural heritage values that should be preserved because they are the carrier of social memory, which allows to define the social, economic and political structure of the society during the period. Factory campuses, which are transformed by keeping the value of urban change (land rant, speculation) at the forefront of various grounds regardless of historical, social and cultural value as cultural heritage and industrial heritage, have been made legislative changes to the management and ownership structure of the industrial branch in which they primarily produce in turkey paradigm by ideological, economic, administrative transformations. The rearrangements for the transition to a free market economy in terms of limiting production and pricing in factories, weakened the bonds of factories with production, which is the main function of the factories, it has prepared the reasons for the transformation, and on the other hand it has accelerated the transformation process.

With the declaration of state investment in the Republic of Turkey, it is known that industrialization activities in Anatolia have gained momentum with state investments. The first established production facilities and campuses were mostly in sugar, tobacco and textile industries. Therefore, it is possible to say that sugar production is one of the primary areas of Turkey's industrialization experience in order to supply the need for consumption. Sugar, which has been transformed into an industrial product since the 19th century and is among the most imported products of the Ottoman Empire, has become inaccessible due to the interruption of international trade during the war years.

Sugar, which is one of the main consumption items of the population, should have been produced in accordance with the national economy policy of the newly established State. Thus, the subject of sugar production and factorization was addressed at the Izmir Economic Congress held in 1923 and the establishment of sugar factories was encouraged with the "Concession and Relief Law Granted to Sugar Factories" numbered 601, which came into force in 1925. In this context, the sugar beet production and establishment of sugar factories were among the priority economic policies of the Republic. After the Law No. 601, Uşak Sugar Factory (1926), Alpullu Sugar Factory (1926), Eskişehir Sugar 
Factory (1933) and Turhal Sugar Factory (1934) were the first established sugar factories. Although sugar production activities have continued by 1950, the capacity of the four existing factories has been increased from time to time, but the establishment of new factories has become mandatory to establish new factories in order to meet the increasing sugar needs with total domestic production each year. "Expansion Program of Sugar Industry" was prepared in 1951. Within the scope of the program, a total of eleven new sugar factories were built and commenced production in Anatolia, including Malatya Sugar Factory (1956) during the period covering 1951-1956. After 1980, the restructuring, which occurred within the framework of global economic policies, revealed a series of economic, social and spatial transformations on a national scale. The change of the state's economic policy as a reflection of these transformations on a national scale has transformed the urban space into an investment area for capital and paved the way for urban transformation practices focusing on different areas of the city to supply the needs of capital. The replacement of industrial production by the construction and finance sectors turned to industrial areas that are public-owned for reasons such as they lost their function or are idle areas in the city. In this context, sugar factories, which are considered as an important tool of the modernization experience that can be considered as industrial heritage and cultural heritage and which can be considered as examples of social factories, have entered a rapid transformation process within the scope of neoliberal urban policies. However, it should be noted that neoliberal economic policies affect sugar policy in Turkey before physical transformation. The first effect was in production capacity as a result of destabilizing beet purchase prices. The second effect was legislative changes to the reorganization of the sugar regime since 1996. Since 1996, legislative changes have been made to reorganization the sugar regime. In 2001, the transformation that occurred as a result of the Sugar Law No. 4634 coming into force; It is possible to qualify as quota implementation in sugar production and supply, the introduction of the free system in beetand sugar prices, and the establishment of the Sugar Authority to carry out all tasks related to the sugar sector in Turkey. The Sugar Committee, the decision body of the Sugar Authority, has the authority to regulate and control the sugar market, especially to determine the supply and quota in sugar production. Simultaneously with the reorganization of the sugar regime, sugar factory campuses and immovables were included in the scope of privatization and property and physical structure transformations were initiated in sugar factory campuses. 
In this context, the process that began with a partial transformation in Malatya Sugar Factory has produced a result that includes the conversion of production areas. The transformation of Malatya Sugar Factory began by lower/ reduced production capacity and reduced number of employees, then continued with property turnover, and subsequently ended with the transformation of the spatial structure. The study reveals the transformation process of Malatya Sugar Factory campus, one of the state-owned industrial campuses in Turkey, through property, function and spatial transformation within the framework of privatization decisions and discusses the bring into different use of economic sectors as a result of interventions rather than protecting it as an industrial heritage.

\section{Kaynakça/References}

Altaş, F. (2020). 'Koruma Karari' siyasi bask ile mi kaldirlld?? http://malatyahaber.com/haber/koruma-karari-siyasi-baski-ile-mi-kaldirildi/ adresinden erişildi.

Asiliskender, B. (2009). Cumhuriyet sonrası kalkınma hareketi olarak sanayileşme ve mekânsal değişim. Türkiye Araştırmaları Literatür Dergisi, 7(13), 153-169.

Ayik, U. ve Avcı, S. (2018). Ekonomik ve mekânsal boyutlarıyla sanayisizleşme. International Geography Symposium on the 30th Anniversary of TUCAUM. 3-6 October 2018, Ankara. 1276-88.

Belge, B. (2004). Çok katmanlı tarihi kent merkezlerinin yönetimi: kentsel arkeoloji ve planlama. Planlama, 30(4), 48-56.

Cengizkan, A. (2000). Türkiye'de fabrika ve işçi konutlarn: istanbul silahtarağa elektrik santrali. ODTÜ Mimarlkk Fakültesi Dergisi, 20(1-2), 29-55.

Cengizkan, A. (2009). Fabika'da barınmak: erken cumhuriyet dönemi'nde Türkiye'de işçi konutlarl: yaşam, mekan ve kent. Ankara: Arkadaş Yaymevi.

Ciravoğlu. A. (2010). Ruhr bölgesini yeniden kurmak için kültürel bir tohum: Zollverein sanayi kompleksinin dönüşümü. Mimar-İst, 10(35), 19-21.

Dicken, P. (1992). Global shift: the internationalization of economic activity. London: Chapman Publishing.

Erbaş, R.G. (2019). Şeker fabrikası artık kültür mirası. Malatya Sonsöz, 2 Şubat 2019 tarihinde, http://www.malatyasonsoz.com.tr adresinden erişildi.

Hazar, G. (2019). Şeker' in lojmanları için koruma kararı. Malatya Haber, 12 Mart 2020 tarihinde, http://malatyahaber.com/haber/sekerin-lojmanlari-icin-koruma-karari/ adresinden erişildi.

Falconer, K. (2005). Industrial archaeology goes universal, Industrial Archaeology Review, $27(1), 23-26$. 
Falser, M. (2001). Global strategy studies, industrial heritage analysis, world heritage list and tentative list. 25 ekim 2017 tarihinde, http://whc.unesco.org/archive/indstudy01.pdf adresinden erişildi.

Föhl, A. (1995). Bauten der industrie und technik, Schriftenreihe Des Deutschen Nationalkomitees Für Denkmalschutz, 47.

Gültekin, N. (2016). Kültür ve endüstri mirası olarak Ankara Şeker fabrikası. İdealkent, 20, 906-935.

Halbwachs, M. (1980/1950). The collective memory. New York: Harper and Row.

ICOMOS. (2011). Joint ICOMOS - TICCIH principles for the conservation of industrial heritage sites, structures, areas and landscapes, (The Dublin Principles). 13 Kasim 2017 tarihinde, https://ticcih.org/about/about-ticcih/dublin-principles/ adresinden erişildi.

Kalaycıoğlu, E. (2012, 15 Ocak). Şeker fabrikası ve anılarım. Malatya Flaş Haber. 05 Ekim 2017 tarihinde, www.flashabermalatya.com adresinden erişildi.

Karaduman, B. (2015, 7 Şubat). Büyükşehir' deki “360 derece malatya” dan eser kalmamış!. Yeni Malatya. 11 Kasım 2017 tarihinde, www.yenimalatya.com.tr adresinden erişildi.

Karayaman, M. (2012). Atatürk döneminde şeker sanayi ve izlenen politikalar. Atatürk Araştırma Merkezi Dergisi, 28(82), 53- 96.

Köksal, G. (2012). Endüstri mirasını koruma ve yeniden kullanım yaklaşımı. Güney Mimarlik, 8, 18-24.

Köksal, T. G. ve Ahunbay, Z. (2006). İstanbul'daki endüstri mirası için koruma ve yeniden kullanım önerileri. İtüdergisi/a, 5(2), 125-136.

Loures, L. (2012), (Re)-Developing post-industrial landscapes: applying inverted translational research coupled with the case study research method. 11 Ekim 2017 tarihinde, https://www.researchgate.net/publication/242159292 redeveloping postındustrial landscapes applyıng inverted translational research coupled with the case study research method adresinden erişildi.

Malatya Valiliği, (t.y). Atatürk ve Malatya. 21 Ekim 2017 tarihinde, http://www.malatya.gov.tr/ataturk-ve-malatya adresinden erişildi.

Saner, M. (2012). Endüstri mirası: kavramlar, kurumlar ve Türkiye'deki yaklaşımlar. Planlama. 1-2. 53-66.

Sikiaridi, E. ve Vogelaar, F. (2009). Yumuşak kentleşme veya planlamada kültürel dönemeç: Ruhr 2010 Avrupa kültür başkenti. Mimarlık. 349. 54-56.

T.C. Remi Gazete, 14 Şubat 1993. Sayı 17959.

T.C. Remi Gazete, 25 Mayıs 1946. Sayı 6316.

Tekeli, İ. (1995). Bir modernite projesi olarak Türkiye'de kent planlaması. Ege Mimarlık, 2(16), 51-55.

TICCIH. (2003). The Nizhny Tagil Charter for the industrial heritage. 11 Ekim 2017 tarihinde, https://www.icomos.org/18thapril/2006/nizhny-tagil-charter-e.pdf adresinden erişildi. 
TICCIH. (2011). The Dublin Principles. 17 Mart 2020 tarihinde, https://ticcih.org/about/about-ticcih/dublin-principles/adresinden erişildi.

Tronti, M. (1962). Factory and society. Quaderni Rossi.(1962)(2). 13 Mart 2020 tarihinde https://operaismoinenglish.files.wordpress.com/2013/06/factory-and-society.pdf adresinden erişildi.

Türkşeker. (2019). 2018 Y1lı Sektör Raporu, 10 Ekim 2019 tarihinde, https://www.turkseker.gov.tr/data/dokumanlar/2018_Sektor_Raporu.pdf adresinden erişildi.

Türkşeker, Özelleştirme yüksek kurulu kararları, 15 Ekim 2017 tarihinde, http://www.turkseker.gov.tr/OYKkararlari.aspx adresinden erişildi.

UNESCO. (1972). Dünya kültürel mirasın korunması sözleşmesi. 11 Ekim 2017 tarihinde, http://whc.unesco.org/en/conventiontext//adresinden erişildi.

UNESCO. (2017). Dünya kültürel miras listesi kriterleri. 11 Ekim 2017 tarihinde, http://whc.unesco.org/en/criteria/ adresinden erişildi. 


\section{Ekler}

\begin{tabular}{|c|c|c|}
\hline $\begin{array}{l}\text { ÖZELLEŞTİIILEN ADA VE PARSEL } \\
\text { NUMARASI }\end{array}$ & $\begin{array}{l}\text { MÜLKİYETİN DEVRE- } \\
\text { DİDİĞI KURUM }\end{array}$ & ALAN KULLANIMI KARARI \\
\hline \multicolumn{3}{|l|}{$2005 / 73$} \\
\hline $1072 \mathrm{ada}, 15$ nolu parsel & TÜRKŞEKER & Şeker Sanayi \\
\hline $1072 \mathrm{ada}, 15$ nolu parsel & Belirtilmemiş & Belirtilmemiş \\
\hline \multicolumn{3}{|l|}{$2006 / 62$} \\
\hline $\begin{array}{l}1072 \text { ada, } 15 \text { nolu parselde şeker üretimi } \\
\text { için gerekli bulunmayan taşınmazlar, } 290 \\
\text { ada } 14,19,25,26,27 \text { ve } 28 \text { nolu parseller ha- } \\
\text { riç tüm taşınmazlar ile } 1072 \text { ada } 19,21 \text { ve } \\
22 \text { parsel no }\end{array}$ & $\begin{array}{l}\text { Malatya Belediye Baş- } \\
\text { kanlığı }\end{array}$ & $\begin{array}{l}\text { Rekreasyon alanı, kamu ve bele- } \\
\text { diye hizmet alanı }\end{array}$ \\
\hline 1072 ada 20 parsel & Diyanet İşleri Başkanlığı & Diyanet hizmetleri \\
\hline \multicolumn{3}{|l|}{$2006 / 90$} \\
\hline $\begin{array}{l}290 \text { ada, } 19 \text { ve } 28 \text { no'lu parsellerden top- } \\
\text { lam } 7.000 \mathrm{~m} 2^{\prime} \text { lik alanin ifraz edildikten } \\
\text { sonra kalan alan }\end{array}$ & $\begin{array}{l}\text { İçişleri Bakanlı̆̆g Emniyet } \\
\text { Genel Müdürlüğ̈ü }\end{array}$ & Emniyet Hizmetleri \\
\hline \multicolumn{3}{|l|}{$2006 / 62$} \\
\hline \multicolumn{3}{|c|}{$\begin{array}{l}\text { Danıştay 13. Dairesi'nin (2006/4210 Esas ) 27/11/2006 tarihli ve 2006/4210 sayılı kararı da dikkate alınarak } \\
\text { iptal edilmiştir. }\end{array}$} \\
\hline \multicolumn{3}{|l|}{$2008 / 11$} \\
\hline $\begin{array}{l}1072 \text { ada } 19 \text { nolu parselden yaklaşık } \\
23.000 \mathrm{~m} 2 \text { alan ile } 289 \text { ada } 3,4,15,16,17, \\
18,19,20,21,22,23,27,28,29,30,31,32, \\
34,35,36,37,38,39,40,41,42,43,44,45, \\
46,47,48,49,50,51,52,53,54, \text { ve } 62,290 \\
\text { ada } 1,2,4,5,6,13,17,20,21,23,30,33,36 \\
\text { nolu parseller ve } 291 \text { ada } 14 \text { nolu par- } \\
\text { selde bulunan hisse (toplam } 200.000 \mathrm{~m} 2 \text { ) }\end{array}$ & Sağlık Bakanlığı & Hastane ve Sağlık Kampusu \\
\hline $\begin{array}{l}1072 \text { ada , } 19 \text { nolu parselden yaklaşık } \\
65.000 \mathrm{~m} 2 \text { alan }\end{array}$ & $\begin{array}{l}\text { Başbakanlık Gençlik ve } \\
\text { Spor Genel Müdürlüğü }\end{array}$ & Spor Tesisi \\
\hline 1072 ada 20 parsel & Diyanet İşleri Başkanlığı & Diyanet hizmetleri \\
\hline $\begin{array}{l}1072 \text { ada } 19 \text { nolu parsel ve parselde bulu- } \\
\text { nan Şeker İlköğretim Okulu }\end{array}$ & Malatya Belediyesi & $\begin{array}{l}\text { Malatya Belediyesinin civarda } \\
\text { ihtiyacı gidermeye yetecek ka- } \\
\text { dar yeri (arsa) tahsis ederek yeni } \\
\text { bir okul yapılıp hizmete girin- } \\
\text { ceye kadar İl Milli Eğitim Mü- } \\
\text { dürlüğü tarafından kullanıl- } \\
\text { ması }\end{array}$ \\
\hline 1072 ada $4,7,8,9,17$, ve 22 nolu parseller & $\begin{array}{l}\text { Malatya Belediye } \\
\text { Başkanlığı }\end{array}$ & $\begin{array}{l}\text { Rekreasyon alanı, kamu ve bele- } \\
\text { diye hizmet alanı }\end{array}$ \\
\hline
\end{tabular}

